\title{
Predictive Open-grown Crown Width Equations for Three Oak Species Planted in a Southern Urban Locale
}

\author{
Nicholas A. Martin, Arthur H. Chappelka, Edward F. Loewenstein, Gary J. Keever, and Greg Somers
}

\begin{abstract}
Models that predict ecosystem services in urban areas are useful tools to urban forest managers. Predictive open-grown crown width equations were developed for three oak species common in urban forests in the southern United States. Tree crown form is an important component of these equations; however, there are few predictive equations available for urban, open-grown trees. The species used were Quercus lyrata Walt. (overcup oak), Quercus nuttallii Palmer (Nuttall oak), and Quercus phellos L. (willow oak). The study authors believe that these are the first predictive open-grown crown width equations developed for these species in the southern U.S. Diameter at breast height (DBH) (independent variable), $\mathrm{DBH}^{2}$ (independent variable), and average crown width (dependent variable) data were used to create the predictive crown width equations and yielded $\mathrm{R}^{2}$ values of 0.96 , 0.94, and 0.91 for overcup, Nuttall, and willow oaks, respectively. These equations can aid urban landscape and utility planners by providing a means to predict crown dimensions at varying trunk diameters. Field time could also be minimized by reducing the need to measure crown width and with time, these equations could be used to validate species specific equations (e.g., leaf biomass) for these and other southern urban-planted tree species.

Key Words. Dimensional Relationships; Open-Grown Crown Width Equations; Predictive Crown Width Equations; Quercus lyrata; Quercus nuttallii; Quercus phellos; Urban Trees.
\end{abstract}

Tree measurements such as tree diameter at breast height $(\mathrm{DBH})$, total height, height to the live crown, and crown width can provide vital information on their own and they provide crucial data for other calculations such as leaf area and leaf biomass (Nowak 1996; Peper et al. 2001a; Peper at al. 2001b). These measurements are important to urban forest managers, arborists, researchers, and planners because they aid in the development of management strategies and practices (Peper et al. 2001a; Peper et al. 2001b). DBH, crown width, leaf area, and other information from trees also aid in assessing ecosystem processes such as evapotranspiration, light interception, and atmospheric deposition (Nowak 1996), and can help in developing predictive equations for pollution uptake (Peper et al. 2001b). Tree measurements are vital when determining ecosystem services and utilizing crown equations makes it possible to determine benefits such as carbon sequestration and air pollution removal. Predictive open-grown crown width equations could also accelerate data collection in the field by only requiring DBH to be measured and using predictive open-grown crown width equations to estimate the crown width, thereby reducing the amount of actual field work. Urban shade trees are vital to our environment and offer many benefits, most of which are dependent on size (Frelich 1992).

Limited research has been conducted on open-grown, predictive crown equations for urban trees (Nowak 1996; Peper et al. 2001a; Peper et al. 2001b; Peper and McPherson 2003), especially for specific regions. However, researchers in the traditional field of forestry have developed numerous equations that include DBH, biomass, and crown width (Krajicek et al. 1961; Ek 1974; Hasenauer 1997; Lhotka and Loewenstein 2008).
Although some of these equations have been used for urban trees, additional validation is lacking (Peper et al. 2001a). Tree canopy architecture differs between open-grown and restricted canopy (i.e., closed canopy, next to a building, etc.) conditions. When grown in the open, a tree's canopy can reach its full size and not be restricted; however, in a forested situation, tree canopies compete for limited growing space and, therefore, may not reach maximum expansion potential. However, other factors, such as soil, light, moisture, and crown loss due to storms or pruning, can also be limiting factors for crown width. Dimensional relationships for urban trees have been calculated on trees with crowns that were full and healthy in New Jersey, U.S. (Fleming 1988), on healthy trees in St. Paul and Minneapolis, Minnesota, U.S. (Frelich 1992), on trees with full tree crowns in excellent condition in Chicago, Illinois, U.S. (Nowak 1996), on street trees in Santa Monica, California, U.S. (Peper et al. 2001a), and on street trees in Modesto, California, U.S. (Peper et al. 2001a; Peper et al. 2001b). The research conducted by Peper et al. (2001a; 2001b) aided in the development of predictive crown width equations for urban trees in regions with longer growing seasons, varying locations, and broader ranges of condition; however, with the available knowledge, there are no equations available for southern United States tree species planted in urban locales.

The goal of the study authors was to develop predictive opengrown crown width equations for three commonly planted urban oak species in the southern U.S.: Quercus lyrata Walt. (overcup oak), Quercus Nuttallii Palmer (Nuttall oak), and Quercus phellos L. (willow oak); using diameter (DBH) and crown width data collected during a $100 \%$ tree inventory to produce the predictive 
open-grown crown width equations. The predictive equations, although created from data obtained from one specific location in the southern U.S., will help in development of future regional equations including other tree species modeled after this approach.

\section{MATERIALS AND METHODS}

\section{Field Data Collection}

Field data were collected on the Auburn University campus $\left(32^{\circ} 36^{\prime} \mathrm{N}, 85^{\circ} 30^{\prime} \mathrm{W}\right)$ located in Auburn, Alabama, U.S. Auburn is in USDA plant hardiness zone $7 \mathrm{~b}$, with minimum temperatures averaging $-15^{\circ} \mathrm{C}$ to $-12^{\circ} \mathrm{C}$ (USDA 2003). Standard i-Tree Eco data were collected following i-Tree Eco protocol (i-Tree 2010a; i-Tree 2010b) during the 2009-2010 tree inventory (100\%) of the managed portions of campus encompassing approximately 243 ha (Martin et al. 2011). Data collected from each tree included $\mathrm{DBH}$, tree height, average crown width, percent dieback, and a relative tree condition rating, among other attributes. i-Tree Eco, originally called the Urban Forest Effects (UFORE) model (i-Tree $2010 \mathrm{c}$ ), was then used to estimate leaf area and leaf biomass by species equations, among other ecosystem services (i-Tree 2010b).

Overcup, Nuttall, and willow oak were selected for the study because they are common southern urban tree species (Dirr 1975), account for large percentages of the campus tree population, and had a broad distribution of diameters (DBH) within the dataset. The species selected were among the ten most numerous tree species on campus, but none of the other common species had sufficient numbers across a wide range of diameters to facilitate model building (Martin et al. 2011). Overcup, Nuttall, and willow oaks have been planted on campus for decades, providing a wide range of diameters. The combination of the size and distribution of the test population provided a good dataset for developing open-grown crown width equations for these common southern U.S. urban tree species.

For this study, the definition of an open-grown tree was modified after Frelich (1992), Nowak (1996), and Hasenauer (1997); a tree was considered open-grown if it was planted in the managed landscape and the canopy was not in direct competition for growing space with other trees or buildings. The overwhelming majority of the trees selected were classified as open-grown, with possibly $1 \%-2 \%$ of the trees having been in slight canopy competition (one side of the tree crown touching the side of a building or another crown) at the time of inventory; however, all trees had leaves present from the top down to the base of the crown on all sides.

DBH and mean crown width data from the inventory were used to create the predictive equations. DBH measurements, recorded to the nearest $0.25 \mathrm{~cm}$, were taken at $1.37 \mathrm{~m}$ above the ground. Mean crown width was determined by measuring along the two cardinal directions (North-South and East-West) from the crown edges (i-Tree 2010a) and averaging the two widths; mean crown widths were rounded to the nearest $0.31 \mathrm{~m}$.

\section{Development of Predictive Equations}

A subset of the total population of each species was created. Each was then divided into $5 \mathrm{~cm}$ classes based on DBH. Data were truncated at the point where there were fewer than ten trees in a class. The maximum DBH measurements used to create the crown width equations for overcup, Nuttall, and willow oak were
$51.1 \mathrm{~cm}, 42.9 \mathrm{~cm}$, and $37.6 \mathrm{~cm}$, respectively. Any outliers (<5) resulting from measurement or recording errors or possible circumstances present at the nursery were removed from the truncated data. Outliers were determined by visually examining data and residual plots were created using DBH and mean crown width and identifying those observations that were $\geq 2$ units larger than the general spread of observations in the same range on the residual plots. Four outliers were removed from the Nuttall oak data, four outliers were removed from the overcup oak data, and none from the willow oak data; resulting in 323 overcup, 243 Nuttall, and 588 willow oak trees remaining for the development of equations. $\mathrm{DBH}$ (independent variable), $\mathrm{DBH}^{2}$ (independent variable), and mean crown width (dependent variable) data were used to derive a regression equation $\left(\mathrm{SAS}^{\circledR}\right.$ 9.2). The equations were of the form:

[1] $\quad$ crown width $=\beta_{0}+\beta_{1} \mathrm{DBH}+\beta_{2}(\mathrm{DBH})^{2}$

The DBH was squared for each tree and was included in the predictive equations to provide the best fit based on residual plot examinations, all of which showed patterns indicating that a higher order term should be added to the model. None of the three species exhibited a pattern in the residual plots after adding the $\mathrm{DBH}^{2}$ term to the model. Without the term in the model, there was a parabolic pattern in the residuals for all three species (data not shown). The inclusion of the $\mathrm{DBH}^{2}$ term in the models was further justified by the fact that much of the existing literature dealing with crown width and DBH includes a $\mathrm{DBH}^{2}$ term (Hasenauer 1997; Lhotka and Loewenstein 2008). Previously published open-grown crown width equations also use a $\mathrm{DBH}^{2}$ term (Paine and Hann 1982; Smith et al. 1992).

To further evaluate the appropriateness of using this information to develop accurate open-grown crown width equations, additional analyses were performed. The data used to develop the initial equations for each species were divided into four groups according to DBH (Table 1). A $20 \%$ subsample of each group was then randomly selected (equaling $20 \%$ of the total population). The subsample was then removed from the population and the remaining $80 \%$ were used to create a new crown width equation. This equation was then used to predict the crown widths of the $20 \%$ subsample. Residual (observed-fitted) values were then plotted against the predicted average crown widths.

Table 1. Summary of Auburn University $100 \%$ tree inventory (2009-2010), showing the number of trees in each DBH category used to further evaluate the predictive open-grown crown width equations for the three selected tree species.

\begin{tabular}{lcccc}
\hline Species & $\begin{array}{c}2.5-12.6 \\
(\mathrm{~cm})\end{array}$ & $\begin{array}{c}12.7-17.7 \\
(\mathrm{~cm})\end{array}$ & $\begin{array}{c}17.8-27.8 \\
(\mathrm{~cm})\end{array}$ & $\begin{array}{c}27.9+ \\
(\mathrm{cm})\end{array}$ \\
\hline Quercus lyrata & 209 & 38 & 15 & 61 \\
Quercus nuttallii & 126 & 59 & 22 & 36 \\
Quercus phellos & 399 & 93 & 66 & 30 \\
\hline
\end{tabular}

\section{RESULTS}

Results regarding DBH and crown width from the $100 \%$ inventory are presented in Table 2 . The field data indicated strong linear relationships for all species (Figure 1), and linear models that were created were significant with all coefficients having a $P$-value $<0.0001$ except for the intercept coefficient for 
Table 2. Summary of the Auburn University $100 \%$ tree inventory (2009-2010) data for the three selected tree species.

\begin{tabular}{|c|c|c|c|c|c|c|c|c|c|}
\hline Species & \# of trees & $\begin{array}{l}\text { Min. DBH } \\
(\mathrm{cm})\end{array}$ & $\begin{array}{l}\text { Max. DBH } \\
\quad(\mathrm{cm})\end{array}$ & $\begin{array}{c}\text { Mean DBH } \\
(\mathrm{cm})\end{array}$ & $\begin{array}{c}\text { Median DBH } \\
(\mathrm{cm})\end{array}$ & $\begin{array}{l}\text { Min. crown } \\
\text { width }(\mathrm{m})\end{array}$ & $\begin{array}{c}\text { Max. crown } \\
\text { width }(\mathrm{m})\end{array}$ & $\begin{array}{l}\text { Mean crown } \\
\text { width }(\mathrm{m})\end{array}$ & $\begin{array}{c}\text { Median crown } \\
\text { width }(\mathrm{m})\end{array}$ \\
\hline Quercus lyrata & 324 & 4.8 & 51.1 & 16.0 & 9.9 & 1.8 & 16.8 & 5.1 & 3.7 \\
\hline Quercus nuttallii & 243 & 6.4 & 42.9 & 15.8 & 11.9 & 2.4 & 14.0 & 5.8 & 4.9 \\
\hline
\end{tabular}

Nuttall oak which had a $P$-value of 0.0009 . The open grown crown width equations developed for the three southern oak species resulted in $\mathrm{R}^{2}$ values of $0.96,0.94$, and 0.91 for overcup, Nuttall, and willow oak, respectively (Figure 1). The residual plot for each species showed no obvious pattern after including the higher order term indicating that the models are appropriate for the data (Figure 2).

A model validation for each species was then conducted by plotting the predicted average crown widths for the $20 \%$ subsample (obtained by using the $80 \%$ equation) against DBH. This yielded an $\mathrm{R}^{2}$ value of $0.98,0.99$, and 0.98 for overcup, Nuttall, and willow oak, respectively (data not shown). Again, residual plots for the $20 \%$ subsamples showed no patterns, indicating that the models are appropriate for the data (Figure 3).

\section{DISCUSSION}

The development of these crown width equations is important to not only provide a tool for designers, developers, and managers, but to also provide a first step in the validation of i-Tree Eco for the southern United States. At the time o this study, these are the first open-grown crown equations developed specifically for oaks common to southern U.S. urban forests. i-Tree Eco uses regression equations to derive measurements of leaf area and leaf biomass (i-Tree 2010b), and to derive accurate measurements in a certain region, equations produced from data collected from trees growing in that region are vital. To date, regression equations used in the model are based on work conducted in Chicago (Nowak 1996). These data have been used extensively (Nowak and Crane 1998; Nowak et al. 2008) and provide good, basic information on relative ecosystem services; however, to regionalize the model, differences in climate, length of growing season, growth patterns, and common tree species need to be considered.

The results demonstrated that $\mathrm{DBH}$ is a reliable predictor for the three species in the study population. Similar growth patterns were observed for all the species tested where with increasing diameters, there were comparable increases in crown width. The strong correlations also indicated that there was minimal management (pruning) performed to control crown spread for these species once they were planted on campus, indicated by large $\mathrm{R}^{2}$ values and continual increase in crown width.

These results indicate that the predictive open-grown crown width equations developed for the three tree species are valid and applicable for use in the Auburn, Alabama region; however, they need to be tested on other sites throughout the southern U.S. Care should be taken when extrapolating these relationships beyond the range of the data or in situations where management practices are used to control crown spread (e.g., pruning). It should also be noted that a large number of trees in these species have been planted within the last ten years, balled-and-burlapped stock sourced from several nurseries. The cultural practices within these nurseries may have affected the crown width/DBH relationship; however, all small diameter trees were used in the equation development because they are now open-grown trees and are typical of what is commonly purchased from nurseries.

Crown width equations developed from urban, open-grown trees are only useful when predicting open-grown crown widths. Using open-grown equations for trees under competition from other trees or adjacent buildings will lead to the $\mathrm{DBH} /$ crown width relationship being over predicted. Speciesspecific equations should also be used when possible to reduce any error. Much research has been conducted on open-grown crown width equations (Ek 1974; Frelich 1992; Nowak 1996; Hasenauer 1997; Peper et al. 2001a; Peper et al. 2001b; Peper and McPherson 2003), but more is needed on species in urban settings, such as the three species described in this study.

Predictive open-grown crown width equations can be very beneficial to urban planners, managers, and arborists, as well as utility planners. Research has been conducted on urban (deVries, 1987; Fleming 1988; Frelich 1992) and forest tree growth estimates (Smith and Shifley 1984), which has led to the ability to estimate diameter growth rates. Using these estimates, it is then possible to estimate crown width and spread at various points in the future based on DBH measurements and the use of predictive open-grown crown width equations. These approximations allow prediction of events prior to planting, such as: time until adequate shade is provided, when a tree crown will reach buildings and other infrastructure, when a tree may become a hazard to the public, and/or when the crown of a tree will reach power lines or other utilities. Such estimates can help urban and utility planners decide if a tree will be planted or if it should be moved, and can also assist in the determination and prediction of future maintenance, like pruning. Managers and arborists can benefit from predictive crown equations by not having to measure crown width while conducting field work. Eliminating the need to measure crown width, which is often times the most difficult and time consuming, will save valuable time. Using existing predictive open-grown crown width equations, and conducting more research to develop more equations for other tree species, can provide tools that can be used by planners in the developmental stages to provide critical information that can be used to enhance the project and prevent future problems.

\section{CONCLUSIONS}

The regression equations developed to predict open-grown crown widths for overcup, Nuttall, and willow oak have potential for use in urban planning throughout the southern U.S. and may be used to validate i-Tree Eco for these species. Using data collected from a region to validate any modeling for that region is crucial and continued research should be carried out in other regions and with other tree species. Equations and models that use accurate field data to validate will help to improve urban forest modeling and provide more accurate results. The use of predictive equations can aid urban developers and utility planners in making the best suitable decisions when it comes to urban tree placement and can provide a valuable time saving tool for managers and arborists. 


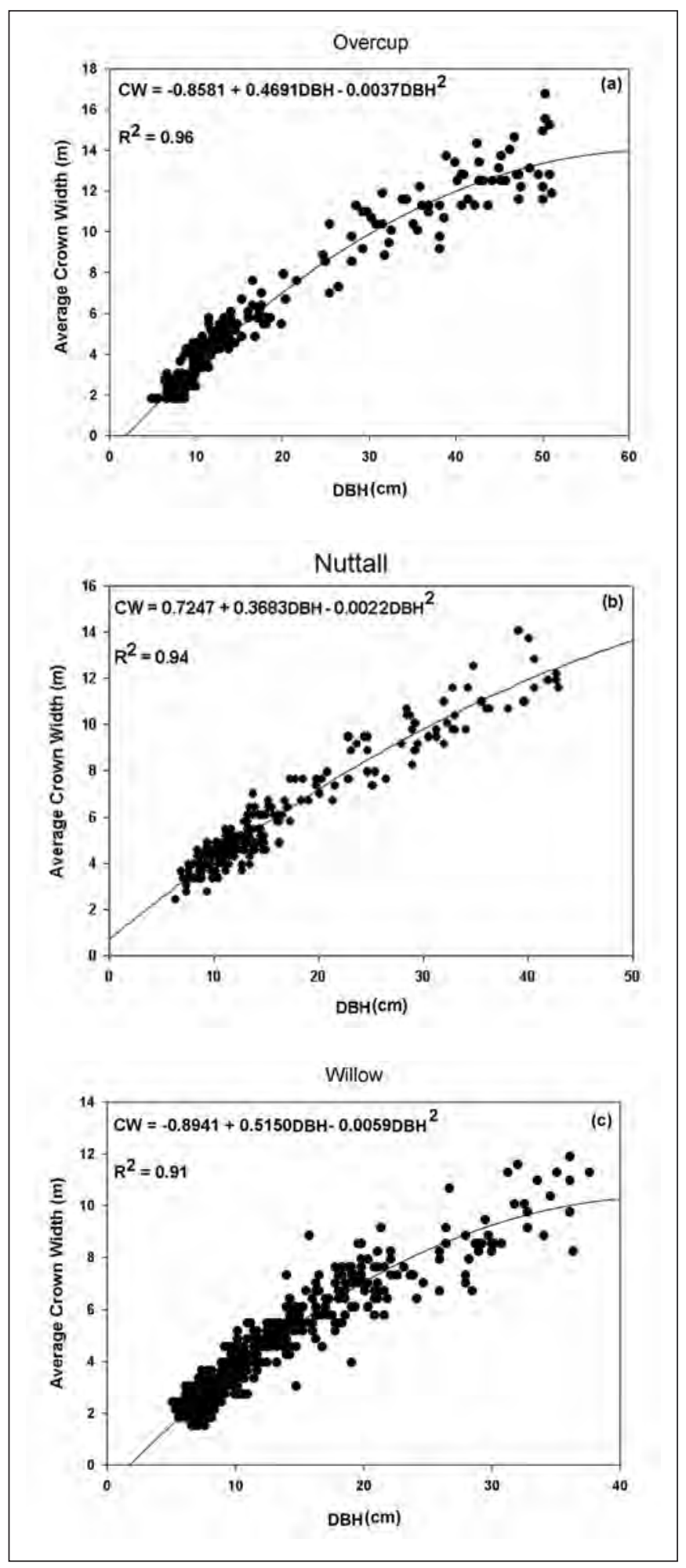

Figure 1. Regression plots for open-grown (a) overcup, (b) Nuttall, and (c) willow oak with DBH $(\mathrm{cm})$ against average crown width (m) using field data collected from during the Auburn University $100 \%$ tree inventory (2009-2010).

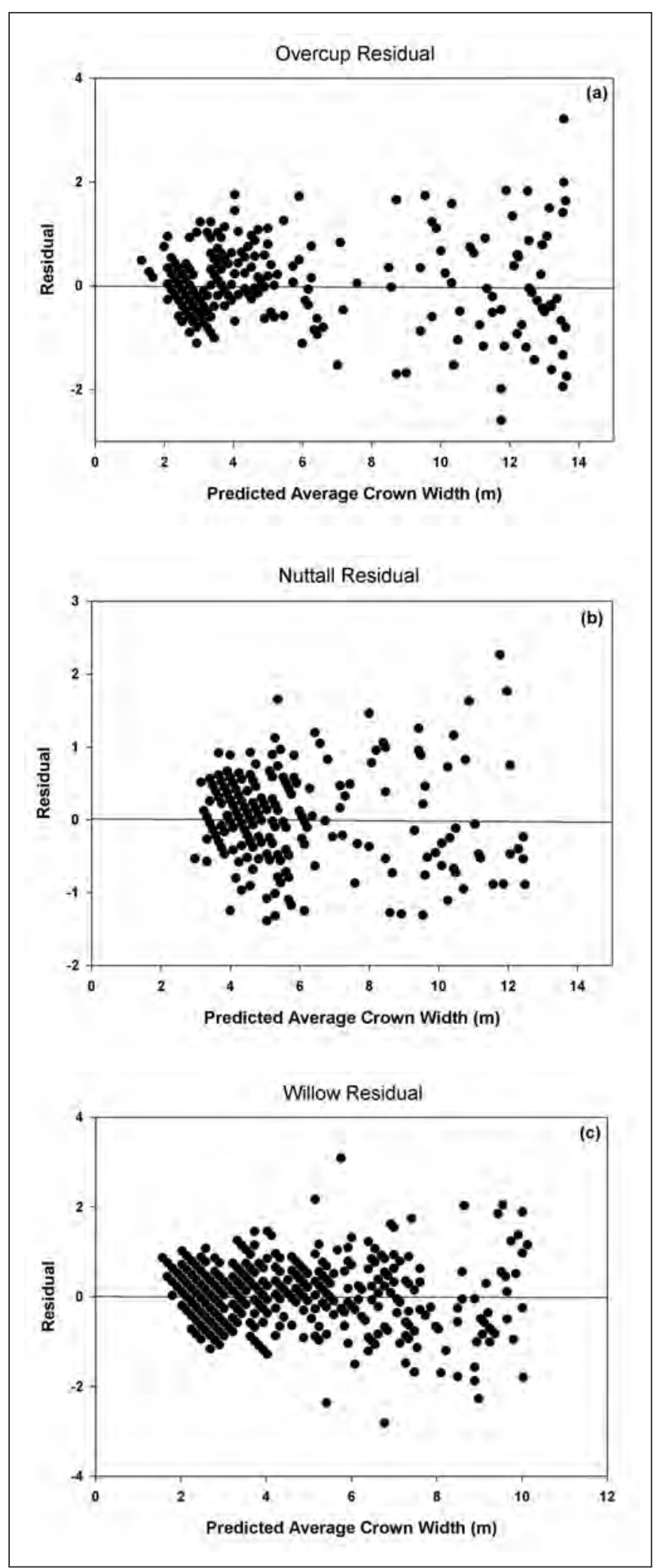

Figure 2. Residual plots created from field data collected during the Auburn University $100 \%$ tree inventory (2009-2010) for (a) overcup, (b) Nuttall, and (c) willow oak with predicted average crown width $(\mathrm{m})$ against the residual values. 


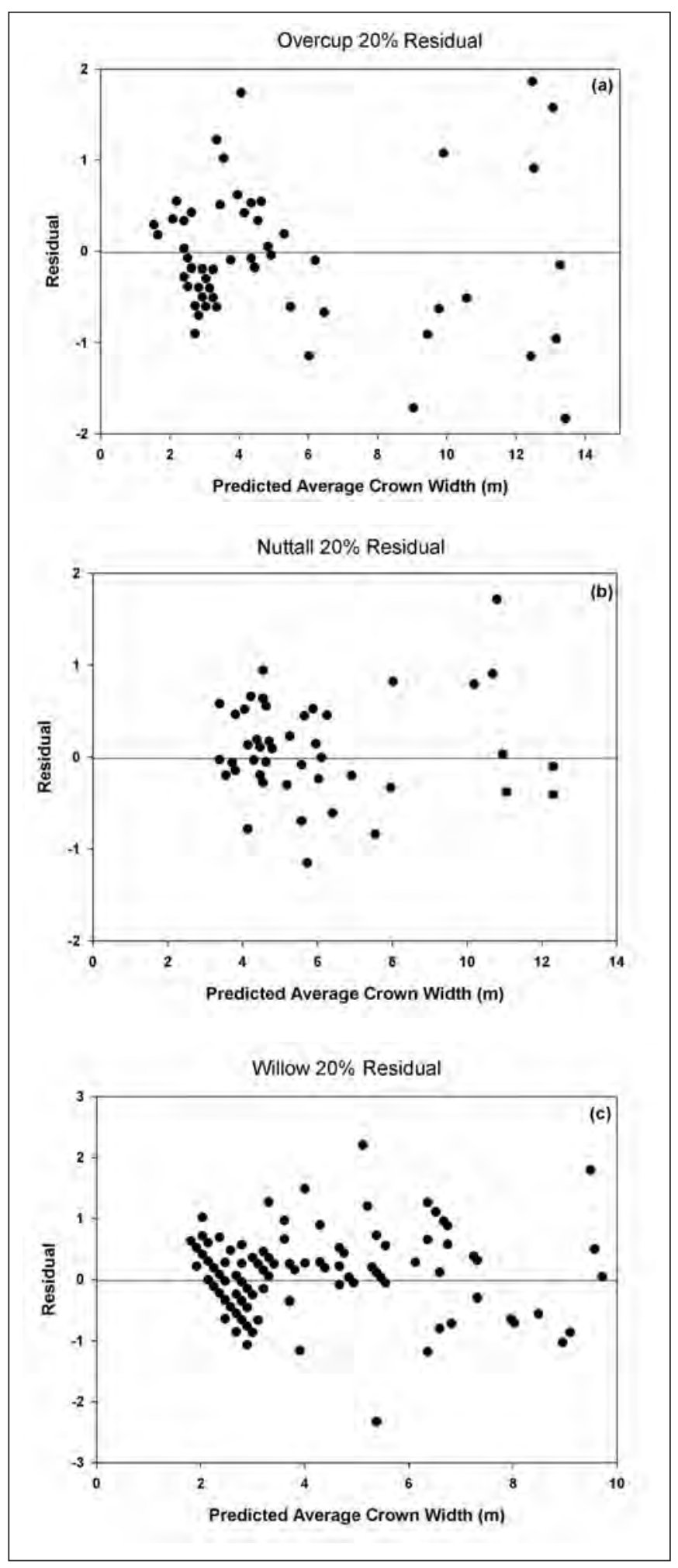

Figure 3. Residual plots created from field data collected during the Auburn University 100\% tree inventory (2009-2010) for the predicted crown widths for the $20 \%$ subsamples for (a) overcup, (b) Nuttall, and (c) willow oak with predicted average crown width (m) against the residual values.
Acknowledgments. We would like to thank Dudley Hartel and Eric Kuehler of the USDA Forest Service-Urban Forestry South office for their assistance and guidance during the duration of this project. We would also like to thank Jonathon Bartlett, Mark Caldwell, Andrew Parker, Elliot Glass, Ann Huyler, and Efrem Robbins for their assistance with data collection; James Ransom and Daniel Mullenix for their technical assistance; Dr. Raymond Kessler for statistical review and the Superintendent of Landscape Services, Charlie Crawford for his assistance throughout the project. This project was funded in part by Auburn University and the USDA Forest Service Co-op Agreement FS-SRS-09CA-11330150-053.

\section{LITERATURE CITED}

deVries, R.E. 1987. A preliminary investigation of the growth and longevity of trees in Central Park. New Brunswick, NJ, Rutgers University, MS. 95 pp.

Dirr, M.A. 1975. Manual of Woody Landscape Plants. Stipes Publishing, L.L.C., Champaign, Illinois, U.S.1187 pp.

Ek, A.R. 1974. Dimensional Relationships of Forest and Open Grown Trees in Wisconsin. University of Wisconsin, School of Natural Resources, Madison, Wisconsin. Forest Research Note 181.

Fleming, L.E. 1988. Growth Estimates of Street Trees in Central New Jersey. M.Sc. thesis, Rutgers Univ., New Brunswick, New Jersey, U.S. 143 pp.

Frelich, L.E. 1992. Predicting Dimensional Relationships for Twin Cities Shade Trees. University of Minnesota. Department of Forest Resources. St. Paul, Minnesota, U.S. 33 pp.

Hasenauer, H. 1997. Dimensional relationships of open-grown trees in Austria. Forest Ecology Management 96:197-206.

i-Tree. 2010a. i-Tree Software Suite v3.1 User's Manual. <www.itreetools. org/resources/manuals/iTree\%20Eco\%20Users\%20Manual.pdf>

i-Tree. 2010b. UFORE Methods. <www.itreetools.org/eco/resources/ UFORE\%20Model\%20FAQs.pdf>

i-Tree. 2010c. i-Tree: Tools for assessing and managing community forests. <www.itreetools.org>

Krajicek, J.E., K.A. Brinkman, and S.F. Gingrich. 1961. Crown competition - A measure of density. Forest Science 7:35-42.

Lhotka, J.M., and E.F. Loewenstein. 2008. An Examination of SpeciesSpecific Growing Space Utilization. Canadian Journal of Forest Research 38:470-479.

Martin, N.A, A.H. Chappelka, G.J. Keever, and E.F Loewenstein. 2011. A 100\% Tree Inventory Using i-Tree Eco Protocol: A Case Study at Auburn University, Alabama. Arboriculture \& Urban Forestry 37(5):207-212.

Nowak, D.J. 1996. Estimating Leaf Area and Leaf Biomass of OpenGrown Deciduous Urban Trees. Forest Science 42:504-507.

Nowak, D.J., and D.E. Crane. 1998. The Urban Forest Effects (UFORE) Model: Quantifying Urban Forest Structure and Functions. Integrated Tools Proceedings. pp. 714-720.

Nowak, D.J., D.E. Crane, J.C. Stevens, R.E. Hoehn, J.T. Walton, and J. Bond. 2008. A ground-based method of assessing urban forest structure and ecosystem services. Arboriculture \& Urban Forestry 34:347-358.

Paine, D.P., and D.W. Hann. 1982. Maximum Crown-Width Equations for Southwestern Oregon Tree Species. Oregon State University, Forest Research Laboratory, Corvallis, Oregon. Research Paper 46.

Peper, J.P., and E.G. McPherson. 2003. Evaluation of Four Methods for Estimating Leaf Area of Isolated Trees. Urban Forestry \& Urban Greening 2:19-29. 
Peper, P.J., E.G. McPherson, and S.M. Mori. 2001a. Predictive equations for dimensions and leaf area of coastal southern California street trees. Journal of Arboriculture 27:169-180.

Peper, P.J., E.G. McPherson, and S.M. Mori. 2001b. Equations for predicting diameter, height, crown width, and leaf area of San Joaquin valley street trees. Journal of Arboriculture 27:306-317.

Smith, W.B., and S.R. Shifley. 1984. Diameter Growth, Survival, and Volume Estimates for Trees in Indiana and Illinois. Research paper NC-257. St. Paul, Minnesota, U.S. Department of Agriculture. Forest Service. North Central Forest Experiment Station. 10 pp.

Smith, W.R., R.M. Farrar, Jr., P.A. Murphy, J.L. Yeiser, R.S. Meldahl, and J.S. Kush. 1992. Crown and Basal Area Relationships of OpenGrown Southern Pines for Modeling Competition and Growth. Canadian Journal of Forest Research 22:341-347.

USDA. 2003. USDA Plant Hardiness Zone Map. <www.usna.usda.gov/ Hardzone/ushzmap.html>

Nicholas A. Martin (corresponding author)

Bartlett Tree Experts

13768 Hamilton Road

Charlotte, NC 28278

nmartin@bartlett.com

Arthur H. Chappelka

School of Forestry and Wildlife Sciences

Auburn University

Auburn, AL 36849

chappah@auburn.edu

Edward F. Loewenstein

School of Forestry and Wildlife Sciences

Auburn University

Auburn, AL 36849

loeweed@auburn.edu

Gary J. Keever

Department of Horticulture

Auburn University

Auburn, AL 36849

keevegj@auburn.edu

Greg Somers

School of Forestry and Wildlife Sciences

Auburn University

Auburn, AL 36849

somergl@auburn.edu

Résumé. Les modèles qui prédisent les bénéfices rendus par les écosystèmes en milieu urbain constituent des outils utiles pour les gestionnaires de forêts urbaines. Des équations de prédiction de la largeur de développement de la couronne en milieu ouvert ont été développées pour trois espèces communes de chênes dans les forêts urbaines du Sud des États-Unis. La forme de la couronne constitue une composante importante de ces équations; néanmoins, il y a peu d'équations de prédiction qui sont disponibles pour des arbres se développant en milieu ouvert. Les espèces étudiées ont été le Quercus lyrata Walt. (chêne à feuille lyrée), le Quercus nuttallii Palmer (chêne de Nuttall) et le Quercus phellos L. (chêne-saule).
Les auteurs de cette étude croient qu'il s'agit des premières équations de prédiction de la largeur de développement de la couronne en milieu ouvert qui ont été développées pour ces espèces dans le Sud des États-Unis. Des données sur le diamètre à hauteur de poitrine (DHP) (variable indépendante), le $\mathrm{DHP}^{2}$ (variable indépendante) et la largeur moyenne de la couronne (variable dépendante) ont été utilisées pour créer les équations de prédictions de la largeur de la couronne et ont produit des valeurs de $\mathrm{R}^{2}$ de $0,96,0,94$ et de 0,91 pour respectivement le chêne à feuille lyrée, le chêne de Nuttall et le chêne-saule. Ces équations peuvent aider les aménagistes et les planificateurs dans leur travail en leur fournissant un moyen pour prédire la largeur de la couronne en fonction de différents diamètres de tronc. Le temps passé sur le terrain à mesurer la largeur des couronnes peut aussi être minimisé en diminuant le besoin de mesurage de la largeur de la couronne, et avec le temps, ces équations pourraient être utilisées pour valider des équations spécifiques à ces espèces (ex.: biomasse foliaire) ainsi que d'autres présentes dans le Sud des États-Unis.

Zusammenfassung. Modelle, welche die ökologischen Vorteile eines Ökosystems in urbanen Räumen vorhersagen können, sind nützliche Werkzeuge für urbane Landschaftsplaner. Gleichungen zur Abschätzung von offen gewachsenen Kronenbreiten wurden für drei Eichenarten entwickelt, die in den südlichen Vereinigten Staaten häufig vorkommen. Die Kronenform ist eine wichtige Komponente dieser Gleichungen, dennoch sind nur wenige voraussehende Gleichungen für urbane, breitkronige Bäume verfügbar. Die verwendeten Arten sind Quercus lyrata Walt., Quercus nuttallii Palmer, und Quercus phellos L.. Die Autoren dieser Studie glauben, dass diese die ersten abschätzenden Kronenausdehnungs-Gleichungen sind, die für diese Baumarten im südlichen Amerika entwickelt wurden. Daten aus Brusthöhendurchmesser (BHD, unabhängige Variable), BHD ${ }^{2}$ (unabhängige Variable) und der durchschnittlichen Kronenbreite ((abhängige Variable) wurden verwendet, um diese abschätzenden Kronenausdehnungs-Gleichungen zu entwickeln und ergaben dabei $\mathrm{R}^{2}$-Werte von 0,96, 0,94 und 0,91 für die drei o. g. Eichenarten. Diese Gleichungen können Landschaftsmanagern und Planern dadurch helfen, indem sie ihnen ermöglichen, die Kronenbreite bei variierenden Stammdurchmessern abzuschätzen. Die Feldzeit konnte dadurch ebenso minimiert werden durch die wegfallende Arbeit, die Kronenbreite zu messen und mit der Zeit können diese Gleichungen genutzt werden, um artenspezifische Gleichungen (z.B. Blattbiomasse) für diese und andere südliche urbane Stadtbäume zu bewerten.

Resumen. Los modelos que predicen los servicios del ecosistema en áreas urbanas son herramientas útiles para los manejadores del bosque urbano. Se desarrollaron ecuaciones predictivas de árboles de copas anchas de crecimiento abierto para tres especies de encinos comunes en bosques urbanos en el sur de los Estados Unidos. La forma de la copa de los árboles es un componente importante de estas ecuaciones, sin embargo, hay pocas ecuaciones predictivas disponibles para árboles urbanos de crecimiento abierto. Las especies usadas fueron Quercus lyrata Walt. (overcup oak), Quercus nuttallii Palmer (Nuttall oak), y Quercus phellos L. (willow oak). Los autores del estudio creen que estas son las primeras ecuaciones predictivas de copas de crecimiento abierto desarrolladas para estas especies en el sur de los E.U. Se usaron datos de diámetro a la altura del pecho (dap) (variable independiente), dap ${ }^{2}$ (variable independiente), ancho promedio de la copa (variable dependiente) para crear ecuaciones con valores de $\mathrm{R}^{2}$ de $0.96,0.94$, y 0.91 para “overcup", "Nuttall", y "willow oak", respectivamente. Estas ecuaciones pueden ayudar a los planeadores de paisajes urbanos proporcionando medios para predecir las dimensiones de la copa a diámetros de tronco variantes. El tiempo de campo pudo también ser minimizado reduciendo la necesidad de medir la amplitud de la copa; con tiempo estas ecuaciones pudiesen ser usadas para validar ecuaciones específicas de especies (ej., biomasa foliar) para estas y otras especies sureñas de árboles plantados. 